\title{
Influence of Business on State Policy within the Framework of Constitutional Economics
}

\author{
Olena Prykhodko \\ ORCID: 0000-0002-5748-9009 \\ Scientific Research Institute of State Building and \\ Local Government of the National Academy of \\ Law Sciences of Ukraine, Kharkiv, Ukraine \\ lena@modelex.mc
}

\begin{abstract}
Nowadays, one of the key issues is the problem of interaction between the state and non-state actors in the context of constitutional economics. The 2020 Coronacrisis has not only revealed the need for a more in-depth analysis of the whole spectrum of this problem - conflict and overlap of interests, competition and partnership of the parties but also raised the importance of the scientific debate to a new level.

The purpose of this article is to study the importance of how enterprises can influence a government's economic policy, including the limits of state interference in the implementation of its current activities in the light of the fundamental constitutional and legal provisions.

The role of entrepreneurship and the influence that non-state economic actors exert on the economic policy of the state is increasing in contemporary conditions. The creation of a mutually beneficial format of interaction between the state and business, which is necessary to maintain the competitiveness of both, necessitates a rethinking of the basic constitutional principles upon which the economic model of the state is based. Under such circumstances, constitutional economics acts not only as a scientific study of existing models, but also assumes the important mission of implementing the objectively formed request to review the basic constitutional economic principles, which were established almost 100 years ago and do not always correspond to the current reality and challenges.
\end{abstract}

Keywords: constitutional economics, Coronacrisis, entrepreneurship, state policy, business. 
Olena Prykhodko. Influence of Business on State Policy within the Framework of Constitutional Economics

\section{Introduction}

Nowadays, one of the key issues is the problem of interaction between the state and non-state actors in the context of constitutional economics. The 2020 Coronacrisis has not only revealed the need for a more in-depth analysis of the whole spectrum of this problem - conflict and overlap of interests, competition and partnership of the parties but also raised the importance of the scientific debate to a new level.

The basis of the constitutional-legal concept of "constitutional economics" was laid by the French Constitution of 1795 (Constitution du 5 Fructidor A, 1975), the content of which imposed obligations on the state regarding freedom and development of entrepreneurship, ensuring property rights. In the $20^{\text {th }}$ century, especially since the $1970 \mathrm{~s}$, lawyers and economists of Italy, France, Germany, Spain, the United States and Portugal have developed a theoretical construct, which aims to explain how and to what extent the Constitution may regulate economic relations. It was determined that in addition to the constitutional text itself, the framework of the constitutional economic order is formed with the administrative and legal functions and powers of the economic block of the government, president, control and supervisory state and advisory (quasi-state) bodies. In the 1990s and early 2000s, after the wave of state-legal experiments to reform the economies of several countries, such as Poland, Chile, Bolivia and Venezuela, following the model of the so-called "shock therapy" that swept across the world, after the collapse of the Soviet Union followed by creation of market economy and democratic constitutions in the new post-Soviet states, a new stage of understanding the legal logic of the very construct and content of constitutional economics began. The high cost of reforms, the loss of human capital, entire industries, and poverty have acutely raised not only the issue of state responsibility for mistakes in carrying out reforms, but also the limits of freedom of economic activity and the principles and methods of state intervention in the commercial sphere. (Laffont, J.-J. and D. Martimort, 2002)

With the onset of the fourth industrial revolution, the question of the balance between the state and the non-state sector, the state and business has reached a new level of political and scientific debate (Ismail, S., Van Geest, Y., 1 Malone, M. (2014). The social state, the socially oriented market economy, social responsibility of business, social entrepreneurship - such issues have formed an active discourse of scientific discussion of an interdisciplinary nature (Davos Manifesto, 2020). However, political and economic crises of recent years in Europe and in the U.S., which significantly worsened with the onset of the 2020-2021 pandemic, brought forward the issue of forming new dimensions of the ratio of public and private interests in establishing the economic balance of the state, increased responsibility of the state for implementing the economic prescriptions of the Constitution. According to the 2020 ILO's World Employment and Social Outlook, $61 \%$ of the world's people work in the shadow economy (International Labour Organisation, 2020). In 2020, $8.8 \%$ of global working hours were lost relative to the fourth quarter of 2019, equivalent to 255 million full-time jobs (assuming a 48hour 
working week). These losses were global and unprecedented, approximately four times greater than that of the Global financial crisis of 2009 (International Labour Organisation, 2021). It is the self-employed, small- and medium-sized businesses that suffer the most.

Whereas previously basic causes of poverty and the wealth gap were known the shadow economy, insufficient fiscal, budgetary and oversight policies, as well as inadequate measures against these phenomena - now it is clear that most states are able to cope with more complex economic challenges brought by the pandemic. Therefore, the quality of law enforcement policy, from the perspective of political science, is labelled as the presence or absence of a political will, becomes apparent not only to specialists, but also to ordinary citizens.

From the point of view of constitutional and legal doctrine, it is the systemic implementation of the basic ideas and principles of the economic constitutional order that matters, such as the concept of the social rule of law, ensuring minimum standards of human rights. At the same time, recent developments have raised a new issue about the state's power to interfere in the functioning of the private sector, restrictions on entrepreneurial activity, economic and social rights and freedoms, which are fundamental to modern democratic regimes (Brennan, G., Pardo, J. C.,1991).

The purpose of this article is to study the importance of how enterprises can influence a government's economic policy, including the limits of state interference in the implementation of its current activities in the light of the fundamental constitutional and legal provisions.

\section{Materials and Methods}

This study is based on a variety of provisions of national constitutions, as well as national legislation in tax, financial and administrative laws of Belgium, Ireland, Italy, Lebanon, Poland, Romania, Slovenia, Sweden, Australia, Liberia, Ukraine, Finland, Tunisia, the Republic of South Africa, Japan, research and statistical data of the International Labour organisation United Nations Office of the High Commissioner for Human Rights and the World Economic Forum.

It uses dialectical, comparative and analytic research methods.

\section{Discussion}

Constitutional economics as a research field comprises but is at the same time broader than, "the economic analysis of constitutional law", as it is pointed out by Ludwig Van den Hauwe. The whole exercise is aimed at offering guidance to those who participate in the discussion of constitutional change (Van den Hauwe, L., 2005). Constitutional economics offers a potential for normative advice in constitutional matters, whereas orthodox economics offers a potential for advice to a practising politician (Buchanan, J. M., 1993). 
In general, constitutional economics mainly analyses activities of public authorities and governance in terms of their relevance to the provisions, principles, and even the spirit of the constitution to ensure the social contract in terms of the economic order. The principles that constitute the constitutional economic order do not exist outside a systemic relationship with other fundamental principles of the constitutional order, especially with the principles of the law-governed and social state, as well as with other constitutional provisions related to the regulation of economic relations.

As a subsystem of constitutional and legal provisions, the economic Constitution covers:

1) principles of the basic constitutional order of freedom of economic activity, common economic space, diversity and equality of different forms of ownership, protection of competition, social nature of the state, importance of generally recognised provisions, as well as principles of international law and provisions contained in international treaties;

2) constitutional provisions of basic economic rights and freedoms and fundamental rights of economic and constitutional significance, as well as of constitutional guarantees of entrepreneurship;

3) provisions establishing the constitutional economic public order:

a) constitutional principles of state regulation of economic activity;

b) provisions with possible limitations of basic economic rights;

c) provisions on the powers of public authorities and local authorities in the field of legal regulation of entrepreneurship.

Currently, the issue of interaction between the state and the entrepreneurship becomes extremely relevant. In market economies, private sector businesses are customers of state services, such as, an effective law enforcement and judicial system, as well as simple and clear rules for economic activity. At the same time business development, stimulation of entrepreneurial activity, and GDP growth directly affect a state's economic development and its ability to perform the functions it has been entrusted with. As such, businesses and the state are destined to constant interaction and its efficiency directly affects them both. The foundations of such interaction are economic principles, fixed at the constitutional level.

The legal concept of the "constitutional economics" or the "Economic Constitution" (according to G. Gadzhiev) reflectively represents the existing of functions that the state should perform in the field of economy (Gadzhiev, G.,2008). The basic principles underpinning this regulatory concept must serve as criteria for the constitutionally permissible penetration of the state into the entrepreneurship field, which is usually an area of private-legal regulation.

The basic elements of the economic Constitution, which are the constitutional provisions fixing economic freedom, human rights in the economic domain, and the limits of their restriction, are almost all genetically linked to civil law. The state, by fixing its economic functions in the constitution, undertakes a new constitutional obligation, by protecting basic economic rights, to observe a reasonable measure in the application of restrictive legal tools. 
Therefore, an important topic is the formation and development of mutual control between state governing agencies and entrepreneurs.

Many contemporary constitutions in various countries have fixed bodies that control public finance. For example, the status of Court of Audit or Court of Accounts, which is a Supreme audit institution, is defined in the constitutions of Belgium, Ireland, Italy, Lebanon, Poland, Romania, Slovenia, Sweden, Australia, Liberia, Ukraine, Finland, Tunisia, the Republic of South Africa, Japan. The constitutional control over the observance of economic rights is of great importance and is institutionalised by the system of ombudsmen.

An important part of the economic constitution are provisions of constitutional law that provide guarantees of public control by the civil society over the process of the state interference in the economy. The improvement of control mechanisms over the state apparatus on behalf of the entrepreneurial community is the reality of modern constitutionalism.

The most common ways of implementing public control and public influence on the economic policy of states are:

1) collective petitions and appeals;

2) uniting in business confederations representing entrepreneurs' interests the Union of Industrialists and Entrepreneurs, Small and Medium Businesses Associations, Chambers of Commerce and Industry, which contribute to policy development, meet with the officials to assess the actions of the government and local authorities, and propose regulatory changes, lobby economic interests of their members;

3) public protests, rallies, demonstrations;

4) strikes;

5) defending their interests in the court.

\section{Conclusions}

There is no doubt that scientific analysis of the events witnessed now will form a new stage of constitutional-legal discourse, first and foremost regarding basic principles, and will strengthen the very meaning of constitutional regulation of economic processes. For a long time, states and governments have been the main drivers of economic policy and formulated the agenda of economic reforms. However, the role of entrepreneurship and the influence that non-state economic actors exert on the economic policy of the state is increasing in contemporary conditions.

The creation of a mutually beneficial format of interaction between the state and business, which is necessary to maintain the competitiveness of both, necessitates a rethinking of the basic constitutional principles upon which the economic model of the state is based. Under such circumstances, constitutional economics acts not only as a scientific study of existing models, but also assumes the important mission of 
Olena Prykhodko. Influence of Business on State Policy within the Framework of Constitutional Economics

implementing the objectively formed request to review the basic constitutional economic principles, which were established almost 100 years ago and do not always correspond to the current reality and challenges.

\section{References}

1. Constitution du 5 Fructidor An III. Available: https://www.conseil-constitutionnel.fr/ [05.03.2021].

2. Laffont, J.-J. and D. Martimort. (2002). The Theory of Incentives - The Principal-Agent Model. Princeton, NJ and Oxford: Princeton University Press, p. 404., Avaliable: https://www.researchgate.net/publication/31737757_The_Theory_of_Incentives_The_Principal-Agent_Model_JJ_ Laffont_D_Martimort [05.05.2021].

3. Ismail, S., Van Geest, Y., Malone, M. (2014). Exponential Organizations: Why new organizations are ten times better, faster, and cheaper than yours (and what to do about it). A Singularity University Book, p. 271.

4. Davos Manifesto. (2020). The Universal Purpose of a Company in the Fourth Industrial Revolution. Available: https://www.weforum.org/agenda/2019/12/davos-manifesto-2020-theuniversal-purpose-of-a-company-in-the-fourth-industrial-revolution/ [05.03.2021].

5. International Labour Organisation, World Employment and Social Outlook, Trends (2020). International Labour Office, Geneva. Available: https://www.ilo.org/wcmsp5/groups/public/--dgreports/---dcomm/---publ/documents/publication/wcms_734455.pdf. [15.03.2021].

6. International Labour Organization. (2021). Periodic report, International Labour Office. Available: https://www.ilo.org/wcmsp5/groups/public/---dgreports/---dcomm/documents/ briefingnote/wcms_767028.pdf [15.04.2021].

7. Brennan, G., Pardo, J. C. (1991). A reading of the Spanish Constitution (1978). Constit Polit Econ 2, 53-79. Available: https://link.springer.com/article/10.1007\%2FBF02393226, [25.04.2021].

8. Van den Hauwe, L. (2005). Constitutional Economics II, In Jürgen G. Backhaus (ed.), The Elgar Companion to Law and Economics, Second Edition, chapter 13, Edward Elgar Publishing, Erfurt University, Germany.

9. Buchanan, J. M. (1993). How can constitutions be designed so that politicians who seek to serve "public interest" can survive and prosper? Available: https://link.springer.com/article/10.1007\% 2FBF02393280\#citeas [17.03.2021].

10. Gadzhiev, G. (2008). Ekonomicheskaya Konstitucia. Konstitucionnie garantii svobodi predprinimatelskoy (economicheskoy) deyatelnosti. Konstitucionniy Vestnik, 1(19), 249-263. (Economic Constitution. Constitutional guarantee of freedom of entrepreneurial (economic) activity. Constitutional Bulletin, 1(19), 249-263.) 